\title{
Hepatocellular progenitor cell tumor of the gallbladder: a case report and review of the literature
}

\author{
Indira Vadlamani ${ }^{1}$ and Elizabeth $\mathrm{M}$ Brunt $^{1,2}$ \\ ${ }^{1}$ Department of Pathology, Saint Louis University School of Medicine, St Louis, MO, USA and ${ }^{2}$ Saint Louis \\ University Liver Center, Saint Louis University School of Medicine, St Louis, MO, USA
}

\begin{abstract}
A 75-year-old man presented to his physician with weakness, anorexia, and constant right upper quadrant pain. He underwent a laparoscopic cholecystectomy, which was converted to an open cholecystectomy due to presumed adhesions. Direct examination of the liver was negative for masses or lesions. A CT scan was negative for masses or nodules. The gallbladder was $8.5 \times 2.5 \mathrm{~cm}^{2}$, with a diffusely thick wall measuring $2.5 \mathrm{~cm}$. Microscopic examination showed a monomorphic tumor consisting of cells with increased nuclear:cytoplasmic ratio and occasional nucleoli, infiltrating the entire gallbladder uniformly. The tumor cells that reacted to antibodies directed against HepPar1, CAM 5.2, CK19 and scattered cells were immunoreactive for CD117, CD34, and CD56. This immunohistochemical profile suggested a 'hepatocellular progenitor cell tumor of the gall bladder'. This report is, to our knowledge, the first such case of a tumor of this cell type reported in the gallbladder. In addition, we present a review of the literature.

Modern Pathology (2005) 18, 864-870, advance online publication, 14 January 2005;doi:10.1038/modpathol.3800367
\end{abstract}

Keywords: gallbladder tumor; hepatic progenitor cells; immunohistochemistry

Primary malignant tumors of the gallbladder are predominantly adenocarcinomas; rarely, lymphoma or sarcoma occur. We recently studied a malignant tumor restricted to the gallbladder with light microscopic and immunohistochemical characteristics of hepatic progenitor cells. ${ }^{1,2}$

\section{Case report}

A 75-year-old Caucasian man presented to his physician with weakness, anorexia, and constant right upper quadrant pain. Past medical history was significant for hypertension, type II diabetes mellitus, and remote appendectomy. He had a remote two packs per day smoking history (30 years prior). He was not jaundiced but was dehydrated and febrile $\left(101^{\circ}\right)$. Laboratory tests of comprehensive metabolic profile, including standard liver tests, were within normal limits. He was anemic (hemoglobin 12.4 $\mathrm{g} / \mathrm{dl}$, hematocrit $36.4 \%$ ) and his white blood cell count was increased $\left(10.8 \mathrm{th} / \mathrm{mm}^{3}\right)$. Current medications included glucophage, glyburide, triamterene/

Correspondence: Dr EM Brunt, MD, 4th Floor, FDT, SLUH, 3635 Vista Avenue, St Louis, MO 63110, USA.

E-mail: bruntem@slu.edu

Received 25 August 2004; revised 9 November 2004; accepted 10 November 2004; published online 14 January 2005 hydrochlorthiazide, lisinopril, and chlordiazepoxide.

Laparoscopic cholecystectomy was attempted, but because of the perception of adhesions, an open cholecystectomy was performed. Intraoperative cholangiogram was negative for gallstones. There were no liver lesions on direct visual examination. Neither perihepatic nor intra-abdominal adenopathy was noted.

There were no nodules or tumors in the thorax, abdomen, or pelvis with computerized tomographic (CT) scan performed on postoperative day 6 .

\section{Pathology}

\section{Gross Pathology (Figure 1)}

The gallbladder measured $8.5 \times 2.5 \mathrm{~cm}^{2}$; the wall was diffusely and uniformly thickened to $2.5 \mathrm{~cm}$. A single dark green, $1.5 \times 1.5 \times 1 \mathrm{~cm}^{3}$, granular, ovoid stone was present. The mucosa was focally hemorrhagic but was otherwise velvety and without lesions.

\section{Microscopic Pathology (Figure 2)}

A monomorphic tumor infiltrated the lamina propria, submucosa, muscularis propria, and serosa. 


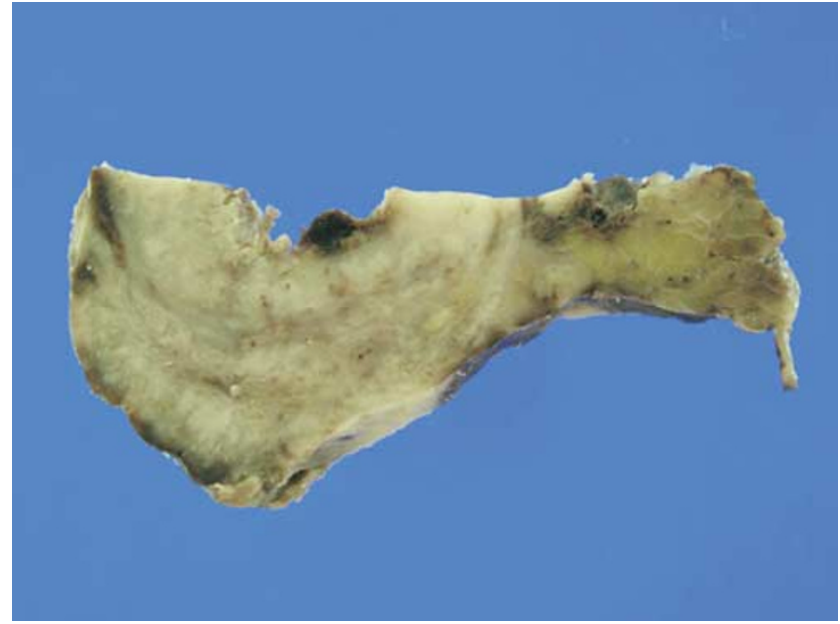

Figure 1 Gross photograph of the gallbladder shows a uniformly thickened wall.
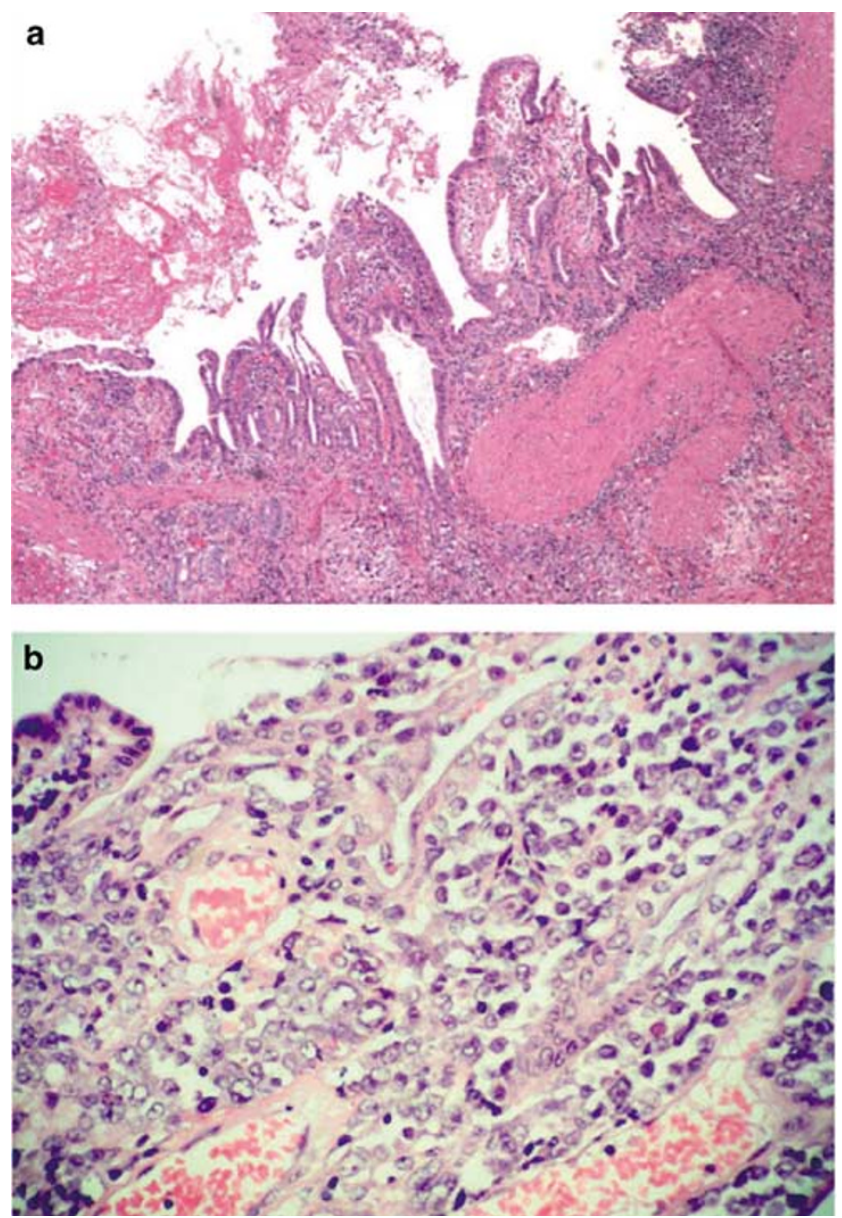

Figure 2 (a) This light microscopic photomicrograph illustrates the unremarkable surface mucosa with a monomorphic tumor within the lamina propria and the submucosa (H\&E). (b) In this higher power field, the tumor cells are oval and show a high nuclear: cytoplasmic ratio, open chromatin, and occasional prominent nucleoli (H\&E).

The surface mucosa was intact and unremarkable, without evidence of dysplasia or in situ carcinoma. The tumor was in sheets and small clusters around vessels, but no evidence of gland or trabecular formation was seen; tumor necrosis was extensive. The tumor cells were round to oval, and showed mild nuclear pleomorphism, increased nuclear: cytoplasmic ratio, margination of chromatin, and occasional prominent nucleoli. Mitoses were rarely noted. Perineural invasion and lymphovascular invasion were seen. Additionally, a dense lymphocytic infiltrate was in the lamina propria, with occasional follicles. The adhesions on the serosal surface were negative for tumor.

\section{Immunohistochemistry (Figure 3)}

Table 1 lists the markers studied in the case. The initial impression of lymphoma was ruled out by a battery of lymphocyte immunohistochemical markers. Immunostains for polyclonal CEA, HMB45, and S-100 were also nonreactive. Positive markers included pankeratin ( $>50 \%$ ), CK7 (in a cluster of tumor cells, <1\%), HepPar1 (positive in $>90 \%$ ), CK19 (focally positive in 25\%), CD117 (scattered tumor cells, $<1 \%$ ), CD34 (scattered tumor cells, $<1 \%$ ), CD56 (scattered tumor cells, $<1 \%$ ), CD10 $(<1 \%)$, EMA (positive in 50\%), and CAM 5.2 (positive in $>50 \%$ ). The surface mucosa was diffusely positive for CK7 and CK19, but there were no single cells positive for CD34, CD117, or CD56 in the epithelium.

Based on the clinical observations and gross findings, the tumor was determined to be a primary gallbladder tumor. Light microscopy and immunohistochemical profile indicated hepatic progenitor cell/intermediate cell origin.

\section{Discussion}

Hepatic progenitor cells in the normal human liver are small round epithelial cells that reside in the most proximal branches of the biliary system, the Canal of Hering. ${ }^{3}$ These cells have been identified as the precursors of the mature hepatocytic and biliary cells. Activated progenitor cells are present in the diseased and regenerating liver. ${ }^{1}$ In rodent studies, these cells have been referred to in a variety of terms, including 'oval cells' ${ }^{4,5}$ In human tissue, subtypes of progenitor cells reflecting different stages of maturation identified by immunohistochemical markers are known to exist. These have been shown in a variety of liver diseases. The immunohistochemical profiles confirm both biliary and hepatocytic phenotypes: OV-6, CK19, CK7, HepPar 1, albumin, neural cell adhesion marker (NCAM-1)(CD56), and stem cell markers: c-kit (CD117) and CD34. ${ }^{1,2,6}$ Similar cells have also been identified in rodent pancreas, ${ }^{7}$ which is derived embryonically with the liver from a common anlage in the endoderm. After pancreatic injury, oval cells in the pancreas have been shown to differentiate 

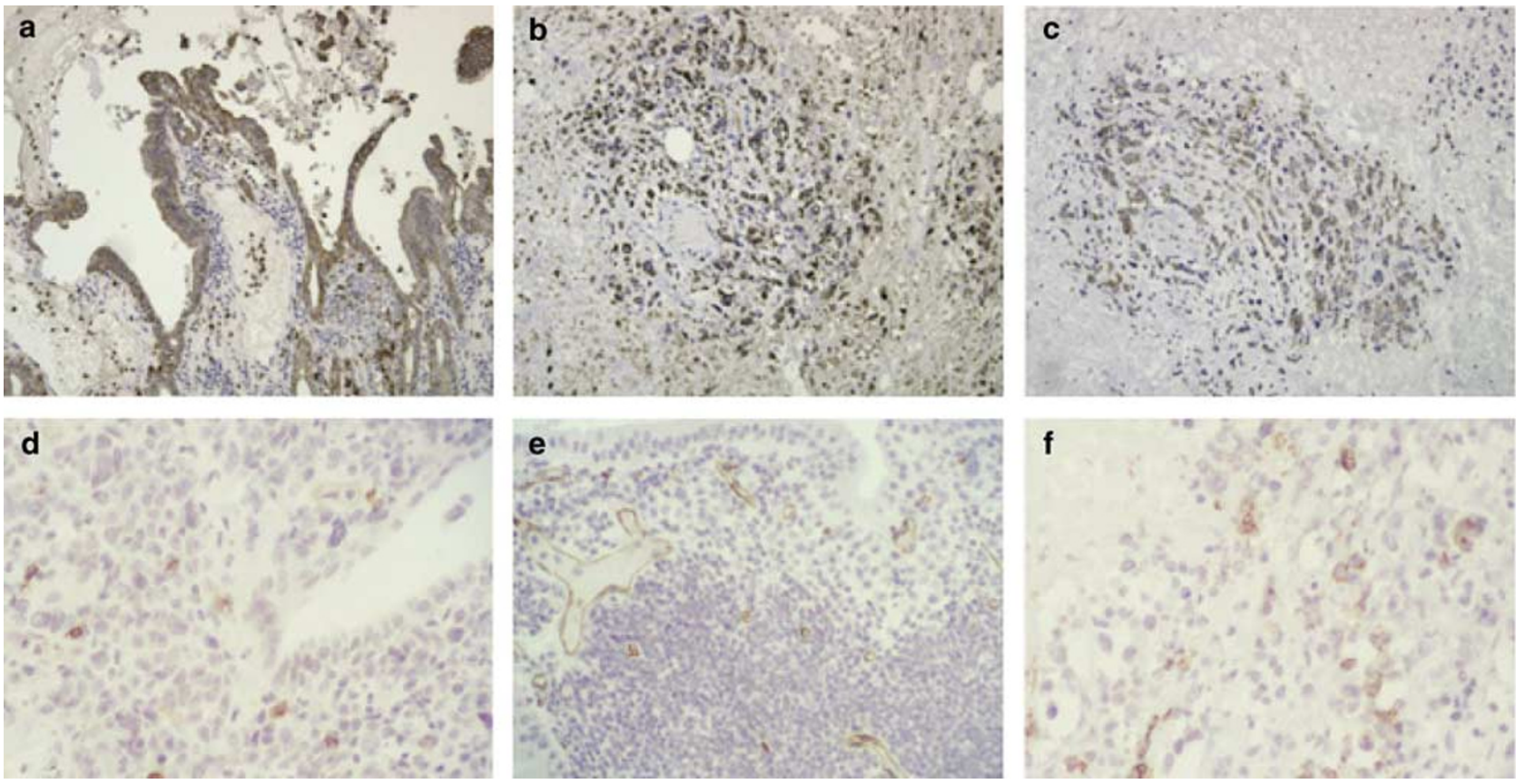

Figure 3 (a-f) Immunohistochemistry panel. See results and Table 1. (a) Pankeratin, (b) CK19, (c) HepPar1, (d) CD117, (e) CD34, and (f) CD56.

into hepatocytes, as determined by expression of genes normally in hepatocytes, including alphafetoprotein, albumin, and alpha-1-antitrypsin.

'Intermediate cells' is the term that has been proposed by Roskams and Theise ${ }^{1,2}$ for the epithelial cells with a morphologic and immunophenotype intermediate between hepatocytes and cholangiocytes that are seen in varying numbers in hepatic regenerative responses to toxic, metabolic, and inflammatory damage to the hepatic parenchyma. In contrast to small size and diffuse cytoplasmic reactivity with CK7 of progenitor cells, intermediate cells have submembranous reactivity of CK7 and lesser degree of CK19 reactivity. Intermediate cells are a component of the reparative and regenerative response of the liver termed the 'ductular reaction' and have been documented in a variety of disorders including alcoholic and nonalcoholic fatty liver disease, cholestatic liver disease, chronic hepatitis and submassive necrosis. The subject has been reviewed in two recent manuscripts. ${ }^{1,2}$

Neoplasms of progenitor cell origin have been proven in the chemical hepatocarcinogenesis models in rodents. ${ }^{8-14}$ Several groups have reported cells with progenitor phenotype in humans with benign tumors (liver cell adenomas), and in malignant tumors in children (hepatoblastomas) and adults (hepatocellular carcinoma, cholangiocarcinoma and mixed phenotypes). Table 2 reviews the reported cases. In some reported cases, tumor cells were described as arranged in trabeculae, and surrounded by a delicate fibrous stroma, ${ }^{15}$ whereas in others, tumors were arranged in strands with vague gland-like structures. ${ }^{16}$ Immunohistochemical reactions demonstrated expression of keratins, Hepatocyte-specific antigen (HepPar 1), albumin mRNA, biliary markers (CK7, CK19), stem cell markers (CK14, CD117, CD34) and a neural marker, NCAM (CD56). Ultrastructural examination has also shown features of both hepatocyte and cholangiocyte differentiation. ${ }^{15}$ It has been postulated that these tumors arise from progenitor cells with a dual phenotype. ${ }^{17}$

Studies of hepatoblastoma have shown varying results. Ruck et $a l^{18}$ showed ultrastructural characteristics of small epithelial cells, which expressed albumin, a hepatocytic marker, and CK7, a marker of biliary differentiation. OV-1 and OV-6, rodent markers of oval cells, were also positive in fetal and embryonal areas. Conversely, Badve et $a l^{19}$ studied 10 hepatoblastomas and found that the oval cell 'like' areas were not positive for any progenitor cell markers (HepPar 1, CD34, bcl2, CK19, alpha-1microglobulin); these authors concluded that the tumor cells were more of an undifferentiated phenotype. The variances in these studies may reflect the challenges of antigen reactivity in different tissue preparations, as Ruck et al utilized frozen tissue sections, while Badve et al utilized paraffin sections. ${ }^{20,17}$

Hearyoung et $a l^{16}$ suggested three classifications of primary liver tumors with morphologic and immunohistochemically defined intermediate phenotype: (i) intermediate carcinomas, (ii) transitional combined hepatocellular and cholangiocarcinomas, (iii) hepatocellular carcinoma-small cell type. In 
Table 1 Immunohistochemical stains

\begin{tabular}{|c|c|c|c|}
\hline Antibody/Company & Dilution & Predicted reactivity & Findings in gallbladder tumor \\
\hline CD 3/Dako Cytomation, CA, USA & $1: 400$ & Pan-T cell & $\begin{array}{l}\text { Negative in tumor } \\
\text { Positive in inflammatory cells }\end{array}$ \\
\hline CD 20/Dako Cytomation, CA, USA & 1:4000 & Mature B cell & $\begin{array}{l}\text { Negative in tumor } \\
\text { Positive in inflammatory cells }\end{array}$ \\
\hline CD30/Dako Cytomation, CA, USA & $1: 200$ & $\begin{array}{l}\text { Anaplastic large cell } \\
\text { lymphomas }\end{array}$ & Negative in tumor \\
\hline KP-1/Dako Cytomation, CA, USA & 1:4000 & Histiocytic & $\begin{array}{l}\text { Negative in tumor } \\
\text { Positive in the inflammatory infiltrate }\end{array}$ \\
\hline Myeloperoxidase/Dako Cytomation, CA, USA & $1: 2000$ & Myeloid blasts & $\begin{array}{l}\text { Negative in tumor } \\
\text { Positive in inflammatory cells }\end{array}$ \\
\hline CD45/Dako Cytomation, CA, USA & $1: 3000$ & Leukocytes & $\begin{array}{l}\text { Negative in tumor } \\
\text { Positive in inflammatory cells }\end{array}$ \\
\hline CD 10/Novocastra, UK & $1: 50$ & Common ALL antigen & $\begin{array}{l}\text { Rare positive tumor cells }(<1 \%) \\
\text { Positive in endothelial structures and } \\
\text { luminal surface epithelium }\end{array}$ \\
\hline CD 117/Dako Cytomation, CA, USA & $1: 200$ & $\begin{array}{l}\text { C-kit protein in progenitor } \\
\text { cells }\end{array}$ & $\begin{array}{l}\text { Positive in less than } 1 \% \text { of tumor } \\
\text { (occasional small cells) } \\
\text { Positive in smooth muscle cells }\end{array}$ \\
\hline CD 34/Dako Cytomation, CA, USA & $1: 400$ & $\begin{array}{l}\text { Human hematopoietic } \\
\text { progenitor cell antigen }\end{array}$ & $\begin{array}{l}\text { Positive in scattered tumor cells }(<1 \%) \\
\text { Positive in endothelial vessels }\end{array}$ \\
\hline MAC 387/Dako Cytomation, CA, USA & $1: 800$ & Macrophages, sarcomas & $\begin{array}{l}\text { Negative in tumor } \\
\text { Positive in inflammatory cells }\end{array}$ \\
\hline S100/Dako Cytomation, CA, USA & 1:4000 & $\begin{array}{l}\text { Melanocytic, neural, } \\
\text { histiocytic }\end{array}$ & Negative \\
\hline MelA/Biocare Medical, CA, USA & $1: 50$ & Melanoma & Negative \\
\hline $\begin{array}{l}\text { AE1/AE3 } \\
\text { Biocare Medical/CA, USA }\end{array}$ & $1: 800$ & Pan keratin & $\begin{array}{l}\text { Positive in }<10 \% \text { tumor } \\
\text { Positive in surface epithelium }\end{array}$ \\
\hline CK7/Dako Cytomation, CA, USA & $1: 400$ & 54 kd simple keratin & $\begin{array}{l}\text { Positive in rare cell }<1 \% \text { of the tumor } \\
\text { Positive in surface epithelium }\end{array}$ \\
\hline Keratin/Dako Cytomation, CA, USA & $1: 5000$ & Epithelial & $\begin{array}{l}\text { Positive in } 50 \% \text { tumor cells } \\
\text { Positive in surface epithelium }\end{array}$ \\
\hline CEA polyclonal/Dako Cytomation, CA, USA & 1:10000 & $\begin{array}{l}\text { Canalicular staining of } \\
\text { HCC }\end{array}$ & Negative \\
\hline CK 19/Dako Cytomation, CA, USA & $1: 50$ & $\begin{array}{l}\text { Cholangiocytes, } \\
\text { progenitor cells }\end{array}$ & Positive in $25 \%$ tumor cells \\
\hline & & & $\begin{array}{l}\text { Positive in surface epithelium, biliary } \\
\text { channels }\end{array}$ \\
\hline EMA/Dako Cytomation, CA, USA & 1:1200 & $\begin{array}{l}\text { Transmembrane } \\
\text { glycoprotein on } \\
\text { epithelium }\end{array}$ & Positive in $50 \%$ tumor cells \\
\hline $\begin{array}{l}\text { Hep Par 1/Dako Cytomation, CA, USA } \\
\text { CAM 5.2/Becton Dickinson, CA, USA }\end{array}$ & $\begin{array}{l}1: 1000 \\
-\end{array}$ & $\begin{array}{l}\text { Hepatocytes } \\
\text { Cytokeratins eight and } 18 \\
\text { (hepatocytes and } \\
\text { cholangiocytes) }\end{array}$ & $\begin{array}{l}\text { Positive in surface epithelium } \\
\text { Positive in }>90 \% \text { tumor cells } \\
\text { Positive in }>50 \% \text { tumor cells }\end{array}$ \\
\hline CD 56/Biodesign International, ME, USA & $1: 20$ & $\begin{array}{l}\text { Neural cell adhesion } \\
\text { molecule }\end{array}$ & $\begin{array}{l}\text { Positive in surface epithelium } \\
\text { Positive in scattered }(<1 \%) \text { tumor cells }\end{array}$ \\
\hline
\end{tabular}

their study of 29 tumors, they demonstrated that survival rates for intermediate carcinomas (75\%) were between that of hepatocellular carcinomas $(62.5 \%)$ and transitional combined hepatocellular and cholangiocarcinoma (80\%) with follow-up ranging from 14 to 18 months.

Our case is a primary tumor of the gallbladder. As a result of lack of gland formation or trabecular structures and the relatively monomorphic appearance of the tumor cells, we initially suspected lymphoma, or, less likely, melanoma. However, the markers for lymphoma and melanoma were negative and immunohistochemical marker positivity for HepPar 1, CK19, and CD117 led to a diagnosis of a tumor of hepatic progenitor cell/intermediate cell phenotype. The paucity of cells reactive for CK7, CD117, CD56, and CD34 may reflect poorly preserved antigenicity in the formalin-fixed specimen. ${ }^{6,17,19}$

The primitive endoderm grows into the mesoderm to develop into the liver and the gallbladder in embryogenesis. ${ }^{21}$ We speculate that progenitor cells in the gallbladder share some or all of the features of hepatic progenitor cells. 
Table 2 Reported studies of tumors with progenitor cell components

\begin{tabular}{|c|c|c|c|c|}
\hline $\begin{array}{l}\text { Reference } \\
\mathrm{Au} / \mathrm{Jn} / / Y \mathrm{r}\end{array}$ & Lesions studied (n) & $\begin{array}{l}\text { Adults or } \\
\text { pediatrics }\end{array}$ & Immunohistochemistry results & Tissue preparation \\
\hline $\begin{array}{l}\text { Roskams }^{23} \\
\text { Histopathology, } 1995\end{array}$ & FNH (23) & N/A & $\begin{array}{l}\text { CK19: decreasing gradient of positivity from periseptal to } \\
\text { centrinodular areas ( } 23 / 23 \text { cases) } \\
\text { CK7: positive, same as above }(23 / 23 \text { cases }) \\
\text { OV6: membranous accentuation, same as above }(23 / 23 \text { cases }) \\
\text { Chromogranin A: intense staining, with a decreasing gradient } \\
\text { (23/23 cases) } \\
\text { NCAM: negative }\end{array}$ & $\begin{array}{l}\text { Frozen and paraffin; } \\
\text { ultrastructural } \\
\text { analysis }\end{array}$ \\
\hline $\begin{array}{l}\text { Ruck}^{18} \\
\text { Histopathology, } \\
1997\end{array}$ & $\begin{array}{l}\text { Hepatoblastoma } \\
\text { (17) }\end{array}$ & Pediatrics & $\begin{array}{l}\text { CK7: in small epithelial cells associated with the tonofilament bundle } \\
\text { OV6: scattered cells in 5/7 fetal areas, } 7 / 10 \text { embryonal areas } \\
\text { Albumin: diffuse cytoplasmic staining in small epithelial cells } \\
\text { (coexpressed CK7) } \\
\text { OV1: scattered cells in } 3 / 7 \text { fetal areas, } 6 / 10 \text { embryonal areas }\end{array}$ & $\begin{array}{l}\text { Frozen ( } 12 / 17 \text { cases) } \\
\text { and paraffin; } \\
\text { ultrastructural } \\
\text { analysis ( } 7 / 17 \text { cases) }\end{array}$ \\
\hline $\begin{array}{l}\text { Robrechts }{ }^{15} \\
\text { Liver, } 1998\end{array}$ & $\begin{array}{l}\text { Malignant } \\
\text { primary liver } \\
\text { tumor (1) }\end{array}$ & Adult & 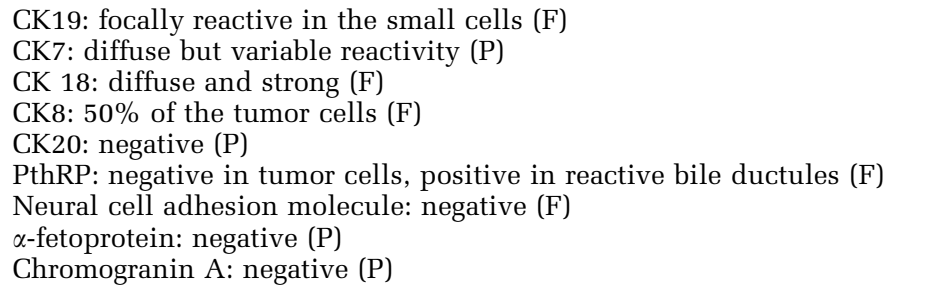 & $\begin{array}{l}\text { Frozen }(\mathrm{F}) \text { and paraffin } \\
\text { (P); ultrastructural } \\
\text { analysis }\end{array}$ \\
\hline
\end{tabular}

Libbrecht $^{24}$

Am J Surg Pathol,

Hepatic adenomas

2001

\section{Uenshi $^{22}$}

Malignant primary 2002

\section{Tickoo $^{25}$}

2002
Am J Surg Pathol,
Malignant primary
liver, tumors, dual phenotype (1)

Malignant primary liver tumors

'CHCC' (27)

HCC (12)

Peripheral CC (7)
Adults

Chromogranin A: negative (P)

CK19: strongly positive (5/10 cases )

CK7: diffuse strong cytoplasmic (5/10 cases)

OV-6: strongly positive (5/10 cases)

Chromogranin A: strongly positive (5/10 cases)

CK8: more intense than in hepatocytes

CK18: more intense than in hepatocytes

Adult

CK19: diffuse (in the central cholangiocarcinoma-like areas)

CK7: diffuse (same)

HepPar 1: focal (in HCC-likeareas)

Adults

CK19: at least $6 \%$ or greater \% positivity in the small cells transitional areas (22/24 cases)

CK7: same as above (23/25 cases)

AE1: same as above (21/22 cases)

CK20: same as above (7/25 cases)

EMA: same as above $(24 / 25$ cases $)$

CAM 5.2: same as above $(21 / 21$ cases $)$

Albumin mRNA: cytoplasmic bluish-black staining in at least $6 \%$ or greater cells (22/23 cases)

Badve $^{19}$

Hepatoblastoma

Mod Pathol, 2003 (epithelial type) (10)
Pediatrics
CK19: negative in small cell component

HepPar 1: negative in small cell componen

Frozen and paraffin; ultrastructural analysis (5/10 cases)

CD34: negative in small cell component

Bcl-2: negative in small cell component

$\alpha_{1}$ microglobulin: negative in small cell component 
Table 2 Continued

\begin{tabular}{|c|c|c|c|c|}
\hline $\begin{array}{l}\text { Reference } \\
A u / J n l / Y r\end{array}$ & Lesions studied (n) & $\begin{array}{l}\text { Adults or } \\
\text { pediatrics }\end{array}$ & Immunohistochemistry results & Tissue preparation \\
\hline $\begin{array}{l}\text { Haeryoung }{ }^{16} \\
\text { J Hepatol, } 2004\end{array}$ & $\begin{array}{l}\text { Intermediate } \\
\text { cell (13) combined } \\
\text { HC (6) small cell HCC } \\
(10)\end{array}$ & Adults & $\begin{array}{l}\text { CK19: in IC cases-from } 5 \text { to }>50 \% \text { of the small cells }(13 / 13 \text { cases) } \\
\text { Combined HC cases-in } 5 \text { to }>50 \% \text { of cells in transitional areas between the } \\
\text { cholangiocytic and hepatocellular areas ( } 6 / 6 \text { cases) } \\
\text { Small cell HCC-5-50\% positive in small cells in a few cases ( } 3 / 10 \text { cases) } \\
\text { CK7: not carried out } \\
\text { HepPar } 1 \text { : IC cases }-5 \text { to }>50 \% \text { of small cells coexpressed with CK19 intensity } \\
\text { (7/13 cases) } \\
\text { In CHC cases }-5 \text { to } 10 \% \text { strong in one case and }>50 \% \text { strong in the rest if the } \\
\text { transitional areas expressed cholangiocytic and the hepatocyte markers ( } 4 / 6 \text { cases) } \\
\text { small cell HCC cases }-5 \text { to }>50 \% \text { of small cells }(9 / 10 \text { cases) } \\
\text { CD117: } 5 \text { to }>50 \% \text { small cells in } 6 \text { tumors IC cases }(10 / 13 \text { cases) } \\
5-50 \% \text { small cells within the transitional zone in combined HC cases (in } 5 / 6 \text { cases) } \\
\text { mostly } 5 \% \text { only in one case } 50 \% \text { small cells in small cell HCC cases }(7 / 10 \text { cases) } \\
\text { and none of these cases expressed CK19 } \\
\text { CEA: cytoplasmic expression in small cells ranging from } 5 \text { to }>50 \% \text { in } 8 / 13 \text { IC } \\
\text { cases and } 4 / 6 \text { CHC cases, and none in small cell HCC cases }\end{array}$ & Paraffin \\
\hline
\end{tabular}

$\begin{array}{ll}\text { Theise }^{17} & \text { Malignant primary } \\ \text { Histopathology, 2003 } & \text { Adults } \\ \text { liver tumors (4) } & \end{array}$
CK19: positivity, ranging from faint to strong in small cells (4/4 cases)

HepPar 1: negative in small cells, positive in HCC components of tumors $(4 / 4$ cases)

Paraffin

CD34: negative in all tumor cells (4/4 cases)

CD117: negative in all tumor cells (4/4 cases)

AE1/AE3: positivity, ranging from faint to strong in small cells (4/4 cases)

$\alpha$-fetoprotein: focally positive in HCC components and a few small cells

$\alpha_{1}$-antitrypsin: focally positive in HCC and negative in small cells

CK 19: positive in $25 \%$ of the tumor cells

CK 7: positive in a small cluster, $<1 \%$ of tumor cells

HepPar 1: $>90 \%$ of tumor cells

CD34: positive in $<1 \%$ tumor cells

CD117: positive in $<1 \%$ tumor cells

CD56: positive in $<1 \%$ tumor cells

AE1/AE3: positive $<10 \%$ of tumor cells

CAM5.2: positive in $>50 \%$ of tumor cells

CK19: cytokeratin 19; CK7: cytokeratin 7; HepPar 1: hepatocyte-specific antigen in paraffin-1; AE1/AE3: simple cytokeratins 8 and 18; CD117: c-kit; CD34: cluster determinant 34; CD56: cluster determinant 56 (neural cell adhesion molecule); CHC: combined hepatocellular cholangiocarcinoma; HCC: hepatocellular carcinoma; CCa: cholangiocarcinoma; FNH: focal nodular hyperplasia; N/A: not available. 
To our knowledge, this is the first report of a primary gallbladder tumor comprising cells with the phenotype of hepatic progenitor/intermediate cells.

\section{Acknowledgements}

The authors appreciate the cooperation of Dr Ron Turgeon of SSM, St Mary's Hospital in St Louis for providing the sections of the tumor and clinical information relating to the case. The authors also wish to thank Dr Neil Theise for his critical reading and thoughtful comments.

\section{References}

1 Roskams TA, Libbrecht L, Desmet VJ. Progenitor cells in diseased human liver. Semin Liv Dis 2003;23: 385-396.

2 Roskams TA, Theise ND, Balabaud C, et al. Nomenclature of the finer branches of the biliary tree: canals, ductules and ductular reactions in human livers. Hepatology 2004;39:1739-1745.

3 Theise ND, Saxena R, Portmann BC, et al. The canals of Hering and hepatic stem cells in humans. Hepatology 1999;30:1425-1433.

4 Farber E. Similarities of the sequence of the early histological changes induced in the liver of rat by ethionine, 2-acetylaminoflourine and 3'-methyl-4dimethylaminoazobenzene. Cancer Res 1956;16:142148.

5 Wilson JW, Leduc EH. Roles of cholangioles in restoration of the liver of the mouse after dietary injury. J Pathol Bacteriol 1958;76:441-449.

6 Seki S, Kitada T, Sakaguchi H, et al. Expression of progenitor cell markers in livers with fulminant massive necrosis. Hepatol Res 2003;25:149-157.

7 Githens S. The pancreatic duct cell: proliferative capability, specific characteristics, metaplasia, isolation, and culture. J Pediatr Gastroenterol Nutr 1988;7: 486-506.

8 Sell S, Dunsford HA. Evidence for the stem cell origin of hepatocellular carcinoma and cholangiocarcinoma. Am J Pathol 1989;134:1347-1363.

9 Everts RP, Nakatsukasa H, Marsden ER, et al. Cellular and molecular changes in the early stages of chemical hepatocarcinogenesis. Cancer Res 1990; 50:3439-3444.

10 Gindi T, Ghazarian DMD, Deitch D, et al. An origin of presumptive preneoplastic foci and nodules from hepatocyte in chemical hepatocarcinogenesis. Cancer Lett 1994;83:75-80.
11 Dunsford HA, Karnasuta C, Hunt JM, et al. Different cell lineages of chemically induced hepatocellular carcinoma in rats defined by monoclonal antibodies. Cancer Res 1989;49:4894-4900.

12 Solt DB, Medline A, Farber E. Rapid emergence of carcinogen induced hyperplastic lesions in a new model for the sequential analysis of liver carcinogenesis. Am J Pathol 1977;88:595-609.

13 Shinozuka H, Lombardi B, Sell S, et al. Early histological and functional alterations of ethionine liver carcinogenesis in rats fed a choline-deficient diet. Cancer Res 1978;38:1092-1098.

14 Sell S, Leffert H, Shinozuka H, et al. Rapid development of large numbers of alpha-fetoprotein containing 'oval' cells in the liver of rats fed N-2-flourenylacetamide in a choline-devoid diet. Jpn J Cancer Res 1981;39:2515-2521.

15 Robrechts C, De VR, Van den HM, et al. Primary liver tumor of intermediate phenotype: a progenitor cell tumor? Liver 1998;18:288-293.

16 Haeryoung K, Chanil P, Kwang-Hyup H, et al. Primary liver carcinoma of the intermediate phenotype. J Hepatol 2004;40:298-304.

17 Theise ND, Yao JL, Harada K, et al. Hepatic 'stem cell' malignancies in adults: four cases. Histopathology 2003;43:263-271.

18 Ruck P, Xiao J-C, Peitsch T, et al. Hepatic stem cells in hepatoblastoma: expression of cytokeratin 7, albumin, oval cell associated antigens detected by OV-1, and OV-6. Histopathology 1997;31:324-329.

19 Badve S, Logdberg L, Lal A, et al. Small cells in hepatoblastoma lack oval cell phenotype. Mod Pathol 2003;16:930-936.

20 Roskams T, Moshage H, Depla E, et al. Parathyroid hormone related peptide is expressed and rapidly inducible in human liver cell cultures that have a bile duct phenotype. J Hepatol 1995;23:160-165.

21 Owen DA, Kelly JK. Gallbaldder and cystic duct: development, anatomy, histology, and congenital anomalies. In: Owen DA, Kelly JK (eds). Pathology of Gallbladder, Biliary Tract and Pancreas. Saunders: Philadelphia, PA, 2001, pp 221-229.

22 Uenshi T, Hiroshi K, Shuto T, et al. Primary liver cancer with dual expression of hepatocyte and bile duct epithelial markers. Hepatogastroenterology 2002; 49:1092-1094.

23 Roskams T, De Vos R, Desmet V. Undifferentiated progenitor cells in focal nodular hyperplasia of the liver. Histopathology 1996;28:291-299.

24 Libbrecht L, De Vos R, Cassiman D, et al. Hepatic progenitor cells in hepatocellular adenomas. Am J Surg Pathol 2001;25:1388-1396.

25 Tickoo SK, Zee SY, Obiekwe S, et al. Combined hepatocellular-cholangiocarcinoma. A histopathologic, immunohistochemical and in situ hybridization study. Am J Surg Pathol 2002;26:989-997. 